\title{
Receptiveness of Spanish and Flamenco Professional Dancers in Their Training and Development
}

\section{Rosa de las Heras-Fernández}

Prof., Facultad de Educación, Universidad Internacional de la Rioja (UNIR), Madrid, Spain,rosa.heras@unir.net

\section{$M^{\mathrm{a}}$ Virginia García Coll}

Prof., Facultad de Ciencias de la Actividad Física y del Deporte, Universidad de Castilla la Mancha (UCLM), Toledo, Spain, virginia.garcia@uclm.es

\section{María Espada}

Prof., Facultad de Ciencias de la Actividad Física y del Deporte (INEF), Universidad Politécnica de Madrid, Spain, maria.espada@upm.es

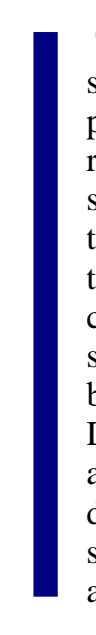

The concept of coaching is an important object of study in the development of sports coaches, and the relationship between athletes and coaches may define the professional life of the former. In the area of dance, the figure of the coach is represented by teachers, choreographers and directors; however, there are few studies that analyse the different forms of coaching and receptiveness in the training of dance professionals. Therefore, the aim of this study was to ascertain the receptiveness of professional Spanish dance and flamenco dancers to the coaching abilities of their respective teachers, directors or choreographers. The sample consisted of 143 dancers, 96 women $(67.1 \%)$ and 47 men (32.9\%) aged between 18 and 51 (30.52 \pm 7.86$)$, who were students in their last year of a Higher Degree, or professionals from different companies specialising in Spanish dance and flamenco. The most relevant results show that there were significant statistical differences in receptiveness to coaching according to age, with the older dancers showing less receptiveness. Similarly, there were significant statistical differences according to the company in which the dancers carried out their professional work.

Keywords: professional dance, flamenco dance, leadership, professional companies, dancer, dance training

\section{INTRODUCTION}

The teachers, choreographers or directors, are essential figures in the training and professional development of dancers, and act as coaches/leaders in each of the stages of 
their careers. It is imperative to understand that leadership and coaching are two very different activities. Leadership is a question of trying to effectively transmit the objectives of the team, and to motivate and move it in a specific direction, while coping with difficult situations. A leader has decision-making powers that directly influence the results of the team. On the other hand, coaching is related to the accompaniment of the athlete. In a coaching context we do not lead, guide or decide what the team or coachee (either individually or as a group) has to do, but rather it is a question of accompanying the person so that they become aware of their skills and abilities and attain the goals that have been marked out or achieve the desired development, in which case the results depends one hundred percent on the coachee. Although the present article deals with coaching, some aspects of leadership that are present in the functions of teachers, choreographers or directors have been taken into account (Sharon, 2016). How the contents are transmitted will influence the motivation of the dancers in their practice. Flamenco is a style of music and dance which has traditionally been transmitted orally (Leblon, 2005). It is included in the forms of Spanish dance which was denoted in 2018 as a representative manifestation of Intangible Cultural Heritage (Ley 10/2015). The traditional form of transmitting the contents in Spanish dance and flamenco has been through observation, imitation and repetition (Arranz, 2012). Initially this took place in different informal contexts in dance companies and groups devoted to mounting shows, and in the dance schools (Pantoja Antúnez, 1963). Flamenco as one of the branches of Spanish dance was included in formal education in Spain in the 1969-1970 academic year (Ley 10/2015). This recent incorporation into formal studies in Spain has meant that there are hardly any studies on coaching, the teaching-learning process or the professional development of dancers in this speciality or in any context of dance; but there are some regarding Physical Education. It can therefore be asked whether the different types of sports coaching could be applied to the context of dance. Could understanding how the dancer perceives the different forms of coaching serve to propose future meaningful coaching methods? To answer these questions the main objective of this study was to understand the receptiveness to coaching of professional Spanish dance and flamenco dancers. Other specific objectives were aimed at ascertaining existing differences in receptiveness according to sex, age and the different dance companies and their professional categories.

\section{REVIEW OF THE LITERATURE}

\section{Leadership and Coaching in Sport}

There are different forms of leadership in sports. Chelladurai and Saleh (1978, 1980) have already presented a multidimensional model with five categories: training behaviour, autocratic behaviour, democratic behaviour, social behaviour and rewarding behaviour. The aim of this investigation was to determine whether certain leadership theories were applicable to the sports environment. These studies aimed to ascertain athletes' preferences regarding their leader's (coach's) behaviour (Chelladurai, 1984; Chelladurai et al., 1988; Chelladurai \& Carron, 1981, 1983; Chelladurai \& Saleh, 1980; Hastie, 1993; 1995; Horne \& Carron, 1985; Sherman, Fuller \& Speed, 2000). Other research has studied the coaches' perception of their own behaviour (Bennett \& 
Maneval, 1998; Brooks, Ziatz, Johnson \& Hollander, 2000; Dwyer \& Fischer, 1988; Horne \& Carron, 1985; Salminen \& Luikkonen, 1994). Williams and Kendall's research (2007), reflects the perceptions of elite trainers and sport scientists on the necessity of investigating the practice of elite coaching. These studies show the interest and importance of knowing the different aspects of sports coaches as leaders and therefore their influence on the development and training of the athlete. Studies by Sánchez, Marcos, Sánchez-Miguel, Amado and García-Calvo (2010) highlight the importance of the sports coach during training for creating a climate involving the task, thus aiming to provoke intrinsic training reasons for the activity itself with the objective of suitably motivating the athletes. In subsequent studies such as the one by Melero (2014) the dimension of social support from the coaches appears as a concept that is more emphasised in a positive leadership style.

\section{The Transmission of Dance Content}

These studies reflect interest in the figure of the coach as a referent in athletes' training and professional development. However, although there are forms of coaching in the area of dance, there are few studies on the figure of the coach. We find studies that demonstrate motor differences in the performance of movements between experienced and beginner dancers (Chia-Wei, Shing-Jye, Fong-Chin, Hong-Wen \& Cheng-Feng Lin, 2014) the results of which can help the teacher, choreographer or director to improve the dancer's performance; however, there are few studies on psychological aspects. Choreographers, directors, and teachers are coaching figures in the education and development of professional dancers. Dance teachers are the first coach a dance student has to face during the learning process, and depending on how they transmit knowledge and motivate the students, the students will feel "pushed" to continue or, on the other hand, drop out of their studies. This is why it is important to emphasise the need to consider the effectiveness of specific coping strategies during the process of training young dancers for a professional career (Barrell, 2001). Studies such as that by Granados (2016) show that the greater the competence of the dance teacher, the higher the level of intrinsic motivation and the lower that of demotivation. Taylor and Taylor (2008) highlight a high level of persistence in training and a great capacity to continue in spite of boredom, fatigue, pain or the desire to do other things in very motivated dance students and teachers. In addition, it is important to bear in mind that the motivational role of feedback in learning is essential in the performance of a continuous motor task (Goudini, Saemi, Ashrafpoornavaee, \& Abdoli, 2018). Other studies on professional dancers (Balaguer, Castillo, Duda, Quested \& Morales 2011) show how the perception of support for the autonomy of the dancer positively influenced autonomous motivation (intrinsic motivation, integrated regulation and identified regulation). These studies on coachability should take into account both leadership aspects and the personality and self-motivation of the dancers (Biasi, Bonaiuto, Giannini \& Chiappero, 1999). Other research on dance has demonstrated a positive relationship between the perception of a climate that involves the task created by the teacher, the satisfaction of basic psychological needs, self-determined motivation and dispositional flow (Alonso et al., 2012); in addition, the satisfaction and self-confidence of the students increases with the practice of dance (Filippou, et al., 2018). The results of Alonso et al. (2012), also 
coincide with the discoveries made in the sports field by authors such as Moreno, Cano, González-Cutre, Cervelló and Ruiz (2009), and Moreno, Cervelló and González-Cutre (2010). Recently, the Resolution of 13th November 2018 by the General Directorate of Fine Arts, defined Spanish dance as an artistic genre of dance that has developed in Spain with different contributions from popular dances, dance in the performing arts and flamenco (Official State Gazette, 2018). Few studies exist on the importance of the psychological training of dance teachers and even fewer on the particular discipline of Spanish dance, whether in the different branches of the bolero, folkloric dances, stylised dance or flamenco (Law 10/2015, of $26^{\text {th }}$ May for the safekeeping of the intangible cultural heritage) or flamenco dancing as an independent discipline (Royal Decree 85/2007). De Rueda \& Requena (2015) affirm that practising dance as it is manifested through flamenco has immense physical and psychological implications which can affect performance and the emotional state. The study carried out in the Conservatory in Seville in three different dance disciplines: contemporary, Spanish and flamenco, is worthy of mention. It describes how a high percentage of students have at some moment thought about abandoning their professional dance studies. Subsequent studies from these same authors (García-Dantas, Caracuel-Tubío \& Peñaloza-Gómez, 2013), proposed an intervention with the teaching board of the Professional Conservatory of Dance in Seville through an experimental study with the aim of improving the motivation of the student body in the practice of dance. The results showed significant variations in the questionnaires on motivation in the experimental group, thus proving the success of the intervention.

In spite of the fact that the importance of the figure of the teacher, director or choreographer for the dancer`s motivation is highlighted in the reviewed articles on dance, none of the studies reflect the dancer's perception of the coaching in any of the dance disciplines.

In conclusion, and given the importance of coaching abilities in dance and the few existing studies in this area, the aim of this study was to ascertain the receptiveness of professional Spanish dance and flamenco dancers to the coaching abilities of their respective teachers, directors or choreographers.

\section{METHOD}

\section{Participants}

A convenience sampling procedure was employed, given the limitations for accessing such an exclusive population. We tried to contact all the dancers in the different dance companies, but it was not possible in all cases and not all of them agreed to collaborate in the study. Dancers were selected from different professional Spanish dance and flamenco companies to which access was available in 2017 and 2018.

The total sample consisted of 143 dancers, 96 women (67.1\%) and 47 men (32.9\%) aged between 18 and 51 (30.52 \pm 7.86$)$. The participants belonged to different Spanish dance and flamenco companies: Luis Ortega, María Pagés, La Zarzuela theatre, Sara Baras, Ballet Colisai, the Spanish ballet in Murcia, the Murcia Company, the Madrid Flamenco Ballet and the Spanish National Ballet. Students also participated from the 
last year of Higher Studies of Spanish Dance and Flamenco: the Alicia Alonso Higher Institute of Dance, the Higher Conservatory of Dance in Madrid, the Barcelona Theatre Institute and the Higher Conservatory of Dance in Malaga.

This project did not pose any ethical or biosecurity issues and all the participants gave their consent to take part.

\section{Instrument}

The instrument used was translated and validated in Spanish to measure coping strategies within the physical activity and sports area (Graupera, Ruiz, García \& Smith, 2011). It comprises 28 items and 7 dimensions (coping with adversity, concentration, confidence and motivation, goal setting, absence of worry, performance under pressure and coachability) with 4 items each. It uses a Likert scale of 1 (completely disagree) to 4 (completely agree) as a score. The internal consistency of the original instrument was high (.86) as was the test-retest correlation coefficient (.87).

The dimension coachability $(\alpha=.70)$ was selected for the adequate development of the present project. The instrument includes four items related to this dimension $(3,10,15$ and 27).

\section{Procedure}

The fieldwork for this study consisted of a standardised questionnaire that was applied at every individual's dance company and which took an average of 20 minutes to complete (Cea, 2004). Informed consent was obtained from all individual participants included in the study. The researchers were present during the administration of the questionnaires to clarify possible doubts and verify the independent completion by the participants.

In this respect, Schensul and LeCompte (1999) add that although this procedure requires greater human effort (both physical and psychological) and more time on the part of the researcher, the research acquires greater rigor.

Control and supervision tasks were carried out during, and at the end of the fieldwork, to make sure the questionnaires were totally and adequately filled in, that is, that all the planned information was collected. Furthermore there was verification that the data were collected as requested (Cea, 2004; Miquel, Bigné, Lévy, Cuenca and Miquel, 2000).

\section{Statistical analysis}

We used the programme SPSS v.22.0 (SPSS Inc., USA) to carry out the statistical analysis. We used descriptive and inferential statistical tests. The descriptive statistics present frequency data such as mean and standard deviations. In the inferential statistics, we used the Kolmogorov-Smirnov test to check the normality of the distributions. In the variables that revealed a normal distribution, we used Student's $t$ test for independent samples and a one-way ANOVA with the aim of analysing the existing relation between the variables. Additionally, we used the Levene test to evaluate the homogeneity of the variances, setting the significance level at $p<.05$. 


\section{FINDINGS}

Table 1 shows receptiveness to coaching in relation to gender. At first, a slight difference of means can be observed between both genders, being higher in men (Table 1). Having explored the data and assumed that the Kolmogorov-Smirnov Normality Criteria had been fulfilled for large samples (>100 individuals), we then carried out the Levene test on homogeneity of variance. Lastly, we performed a t test for independent samples, in which we found that there were no statistically significant differences between both genders: $t(101.145)=.164, p=.87$

Table 1

Receptiveness to Coaching in Relation to Gender

\begin{tabular}{llllll} 
& Gender & $\mathrm{N}$ & Mean & Standard deviation & Standard error of the mean \\
\hline Receptiveness to & Men & 46 & 2.58 & .369 & .054 \\
\cline { 2 - 6 } coaching & Women & 96 & 2.57 & .426 & .043 \\
\hline
\end{tabular}

As for receptiveness to coaching regarding age, in Table 2 we can observe differences in means with the younger dancers (18-28 years of age) presenting a higher mean of receptiveness to coaching than the older dancers (40-51 years of age). Furthermore, there were statistically significant differences, $F(2)=4.722, p=.01$, between the older dancers (40-51 years of age) and the dancers of 29-39 years of age $(p=.01)$ (Table 3$)$.

Table 2

Descriptive Statistics of Receptiveness to Coaching in Relation to Age

\begin{tabular}{llll}
\hline & N & Mean & Standard deviation \\
\hline $18-28$ years of age & 67 & 2.619 & .387 \\
29-39 years of age & 51 & 2.632 & .425 \\
$40-51$ years of age & 22 & 2.340 & .366 \\
\hline
\end{tabular}

Table 3

Multiple Comparisons of Receptiveness to Coaching in Relation to Age

\begin{tabular}{|c|c|c|c|c|c|c|}
\hline \multirow{2}{*}{$\begin{array}{l}\text { (I) Ranges of } \\
\text { years }\end{array}$} & \multirow{2}{*}{$\begin{array}{l}(\mathrm{J}) \text { Ranges of } \\
\text { years }\end{array}$} & \multirow{2}{*}{$\begin{array}{l}\text { Differences of } \\
\text { means (I-J) }\end{array}$} & \multirow{2}{*}{$\begin{array}{l}\text { Standard } \\
\text { error }\end{array}$} & \multirow[t]{2}{*}{ Sig. } & \multicolumn{2}{|c|}{ Confidence interval 95\% } \\
\hline & & & & & Lower limit & Upper limit \\
\hline \multirow{2}{*}{$18-28$} & $29-39$ & -.012 & .074 & .983 & -.188 & .162 \\
\hline & $40-51$ & $.278^{*}$ & .097 & .014 & .046 & .510 \\
\hline \multirow{2}{*}{$29-39$} & $18-28$ & .012 & .074 & .983 & -.162 & .188 \\
\hline & $40-51$ & $.291^{*}$ & .101 & .013 & .050 & .532 \\
\hline \multirow{2}{*}{$40-51$} & $18-28$ & $-.2784^{*}$ & .097 & .014 & -.510 & -.046 \\
\hline & $29-39$ & $-.2914^{*}$ & .101 & .013 & -.532 & -.050 \\
\hline
\end{tabular}

*. The difference in means is significant at level 0.05 .

If we analyse receptiveness to coaching in each of the dance companies studied (Table 4), we can observe a difference in means, with the Sara Baras company and the last year students of the Barcelona Theatre Institute presenting a higher score as opposed to Luis Ortega's company and the group of independent "bailaores" (dancers), who presented the lowest means. Furthermore, there were statistically significant differences, $F(13)=$ 2.765, $p<.01$ between the Sara Baras company and Luis Ortega's company $(p<.01)$ and the independent "bailaores" and Luis Ortega's company $(p<.01)$. 
Table 4

Descriptive Statistics of Receptiveness to Coaching in Relation to the Company

\begin{tabular}{llll}
\hline Name of the Company & N & Mean & Standard deviation \\
\hline Luis Ortega & 7 & 2.142 & .377 \\
María Pages & 9 & 2.583 & .216 \\
La Zarzuela theatre & 9 & 2.694 & .446 \\
Sara Baras & 6 & 3.125 & .209 \\
Ballet Colisai & 4 & 2.625 & .478 \\
Spanish Ballet in Murcia & 19 & 2.552 & .318 \\
Independent "Bailaores" & 18 & 2.305 & .398 \\
Murcia company & 7 & 2.678 & .672 \\
Barcelona Theatre Institute & 3 & 2.750 & .661 \\
Higher Conservatory of Dance in Malaga & 4 & 2.625 & .433 \\
Alicia Alonso Higher Institute of Dance in Madrid & 9 & 2.666 & .250 \\
Higher Conservatory of Dance in Madrid & 12 & 2.729 & .291 \\
Spanish National Ballet & 20 & 2.600 & .383 \\
Madrid Flamenco Ballet & 15 & 2.550 & .343 \\
Total & 142 & 2.5792 & .407 \\
\hline
\end{tabular}

When analysing receptiveness to coaching depending on the dancer's category, Table 5 shows there is a slight difference in means, with higher scores in the dancers that are in the ensemble category $(X=2.63)$ and lower scores in the group of soloists, main dancers, first dancers, and independent dancers $(X=2.50)$. In the Levene or homogeneity of variances test, we did not observe statistically significant differences between variances. Lastly, we carried out the $t$ Test for independent samples, in which we found that there were no statistically significant differences between both groups, $t$ $(102.212)=1.754, p=.08$

Table 5

Descriptive Statistics of Receptiveness to Coaching in Relation to Category

\begin{tabular}{llllll}
\hline & Category group & $\mathrm{N}$ & Mean & $\begin{array}{l}\text { Standard } \\
\text { deviation }\end{array}$ & $\begin{array}{l}\text { Standard error } \\
\text { of the mean }\end{array}$ \\
\cline { 2 - 5 } Coachability & Ensemble & 78 & 2.634 & .379 & .042 \\
\cline { 2 - 5 } & $\begin{array}{l}\text { Soloists, main dancers, } \\
\text { first dancers }\end{array}$ & 54 & 2.504 & .443 & .060 \\
\hline
\end{tabular}

\section{DISCUSSION}

Reviewing the results, we can observe that there are no statistically significant differences between both genders, as men and women dancers showed a similar degree of receptiveness to coaching from teachers, directors and choreographers. However, we do see significant differences regarding age, with the younger dancers (18-28 years of age) being the ones that presented a higher mean in receptiveness to coaching as opposed to the older dancers (40-51 years of age). The younger dancers are at the end of their higher education or entering the professional world and their maximum reference are their teachers. Intervention proposals have been mentioned for improving the teaching in the staff of a professional conservatory (García-Dantas, Caracuel-Tubío, and Peñaloza-Gómez, 2013). Perhaps it would be advisable for such interventions also to be implemented in areas of higher education and professional environments, where there 
are older dancers. On the other hand, we have to take into account, as affirmed by Pedraja (2002), that the teacher as a leader, in their transformational stage, should be able not only to help the students be aware of their possibilities and real capacities, but also help them be able to understand the competitive professional environment. The figure of the choreographer or director as a leader does not seem to have such an impact on the older dancers, according to the perception of the dancers themselves. However, we have to highlight that leadership skills in artistic direction are an ability that can be developed and learned (Gustems, Calderón \& Oriola, 2015).

Regarding receptiveness to coaching in each of the Spanish dance and flamenco companies and the last year students of the Higher Degree, we have seen differences in the means, with the Sara Baras company and the last year students of the Higher Degree showing a higher score regarding receptiveness to coaching, as opposed to Luis Ortega's company and the group of independent "bailaores". The significant differences between the dancers of the Sara Baras company and Luis Ortega's company regarding receptiveness to coach from their directors/choreographers should be taken into account when it comes to proposing motivational strategies, since most studies are developed in the field of sports, and investigations such as Melero's (2004) could be extrapolated to the discipline of dance in order to be able to generate a refinement programme for choreographers and directors. Probably, the fact that a choreographer or director knows how their dancers receive indications helps them adjust and adopt different leadership styles, such as the ones proposed in sports by Chelladurai and Saleh $(1978,1990)$. On the other hand, and still presenting lower means, the results also provided evidence of significant differences between Luis Ortega's company and the group of independent "bailaores", with this group being more receptive to coaching. The independent flamenco artist creates according to a peculiar confrontation between tradition and personality (Berlanga, 2009). It should be underlined that this independent group of "bailaores" devotes itself exclusively to flamenco, alternating more choreographed dances with more improvised dances (Pablo \& Navarro, 2007). This model of more improvised flamenco is usually developed individually and in small venues constituting what Cruces calls "baile corto" [short dance] $(2004$, p. 165). This is where the flamenco "bailaores" "contribute their personality in every interpretation" (Arranz 2012, p.104). Thus flamenco art expresses the most deeply-rooted feelings of the artist; it is a natural state that emerges and is transmitted firmly and with rotundity, where the soul is bared and all the emotions that the moment offers and are felt by the artist are manifested by means of the body (Pérez- Castaño \& Amado, 2015).

This individuality of the "bailaores" who work autonomously implies that normally they are not counting on directions from choreographers or directors. Perhaps that is why they could be more receptive to training. Finally, and despite means with slightly higher scores for receptiveness to coaching in the dancers that are in the ensemble category, the results did not highlight statistically significant differences regarding soloists, main dancers or first dancers, so it does not seem that their professional category affects their being more or less receptive to a coach. However, the choreographer or director needs to understand aspects such as the peculiarities of the company they lead or the category of their dancers to carry out adequate adaptations. These aspects have already been 
taken into account in investigations in the field of sports, such as the studies by Sáiz and Calvo (2010). This is fundamentally about adapting leadership models according to their objectives, if they are looking to train the dancers, to achieve success, or both. Ultimately, implementing a way of coaching that is efficient is understood as the fastest and most accurate way of being able to remember and apply adequate knowledge in a particular context (Schwartz, Bransford, \& Sears, 2005).

\section{CONCLUSION}

The results of the research do not show significant differences among disciplines but do show them with regard to age, as the younger dancers are those that present a higher mean in receptiveness to coaching. With regard to the different companies of Spanish dance and flamenco, it is worthy of mention that the members of the Sara Baras company and the students in the last year of the Barcelona Theatre Institute scored higher regarding receptiveness to coaching. Luis Ortega's company and the group of independent "bailaores" obtained lower means, in spite of which the group of independent "bailaores" showed greater receptiveness to coaching.

Finally, it would be interesting if the data shown in this study regarding the receptiveness to coaching of professional Spanish dance and flamenco dancers could lead to investigations into the different forms of leadership in dancers' training and management in further studies. The results presented with regard to sex, age, companies or professional categories, could give guidelines to teachers, directors and choreographers to improve their leadership functions. These data could also be useful not only for the disciplines of Spanish dance and flamenco, but also for other dance disciplines.

\section{REFERENCES}

Alonso, D. A., Miguel, P. A. S., Marcos, F. M. L., Oliva, D. S., Ponce, I. G. \& Chamorro, J. M. L. (2012). Análisis de los procesos motivacionales sobre el flow disposicional y la ansiedad y su incidencia sobre la intención de persistencia en conservatorios profesionales de danza. Arte y Movimiento, Interdisciplinary Journal of the Department of Didactics of Musical, Plastic and Body Expression, 6, 37-51.

Arranz A. (2012). El baile flamenco. Madrid: Esteban Sanz Martínez.

Alvira, F. (2002). Diseños de investigación social: Criterios operati- vos. In F. Alvira, M. García Ferrando, \& J. Ibáñez (Eds.), El análisis de la realidad social. Métodos y técnicas de investigación (pp. 99-125). Madrid: Alianza editorial.

Balaguer, I., Castillo, I., L Duda, J., Quested, E., \& Morales, V. (2011). Predictores socio-contextuales y motivacionales de la intención de continuar participando: Un análisis desde la SDT en danza. RICYDE. Revista Internacional de Ciencias del Deporte, 7(25), 305-319. doi:10.5232/ricyde2011.02505.

Barrell, G. M. (2001). Coping strategies used by ballet dancers: effects of individual differences in competitive trait anxiety (Unpublished doctoral dissertation). University of Southern Queensland. 
Bennett, G., \& Maneval, M. (1998). Leadership styles of elite Dixie youth baseball coaches. Perceptual \& Motor Skills, 87(3), 754-754.

Berlanga M. A. (2009) La originalidad musical del flamenco: libertad creativa y sometimiento a cánones. La Nueva Alboreá, 10, 32-34.

Biasi, V., Bonaiuto, P., Giannini, A. M., \& Chiappero, E. (1999). Personological studies on dancers: Motivations, conflicts, and defense mechanisms. Empirical Studies of the Arts, 17(2), 171-186.

Boletín Oficial del Estado (2018). Resolución de 13 de noviembre de 2018, de la Dirección General de Bellas Artes, por la que se incoa expediente de declaración de la Danza Española como manifestación representativa del Patrimonio Cultural Inmaterial. Miércoles 12 de diciembre de 2018 Sec. III. Pág. 121894-121908.

Brooks, D. D., Ziatz, D., Johnson, B., \& Hollander, D. (2000). Leadership behavior and job responsibilities of NCAA division 1A strength and conditioning coaches. Journal of Strength and Conditioning Research, 14(4), 483-492.

Cea, Ma. A. (2004). Métodos de encuesta. Madrid: Síntesis.

Chelladurai, P., \& Saleh, S. D. (1980). Preferred leadership in sports. Canadian Journal of Applied Sport Sciences, 2, 85-92

Chelladurai, P. (1984). Discrepancy between preferences and perceptions of leadership behavior and satisfaction of athletes in varying sports. Journal of Sport and Exercise Psychology, 6(1), 27-41. doi:10.1123/jsp.6.1.27.

Chelladurai, P., \& Carron, A. V. (1981). Applicability to youth sports of the leadership scale for sports. Perceptual and Motor Skills, 53(2), 361-362. https://doi.org/10.2466/pms.1981.53.2.361.

Chelladurai, P., \& Carron, A. V. (1983). Athletic maturity and preferred leadership. Journal of Sport Psychology, 5, 371-380. doi:10.1123/jsp.5.4.371.

Chelladurai, P., Imamura, H., Yamaguchi, Y., Oimnuma, Y., \& Miyauchi, T. (1988). Sport leadership in a cross-national setting: the case of Japanese and Canadian university athletes. J. of Sport y Exercise Psyc, 10, 374-389. doi:10.1123/jsep.10.4.374.

Chelladurai, P., \& Saleh, S. D. (1980). Dimensions of leader behavior in sports: development of a leadership scale. Journal of Sport Psychology, 2, 34-45.

Chia-Wei Lin, Shing-Jye Chen, Fong-Chin Su, Hong-Wen Wu, \& Cheng-Feng Lin (2014) Differences of ballet turns (pirouette) performance between experienced and novice ballet dancers. Research Quarterly for Exercise and Sport, 85(3), 330340, doi: 10.1080/02701367.2014.930088.

Cruces, C. (2004). El flamenco en la Universidad. Presentación de una experiencia curricular y docente. In M. López (Ed.), Introducción al flamenco en el currículum escolar (pp. 107-171). Madrid: Akal. 
De Rueda, B., \& Requena, C. M. (2015). Educación emocional para la mejora de la motivación y la autoestima en jóvenes estudiantes de baile flamenco, Cultura, Ciencia y Deporte,11(10), S127.

Dwyer, J. J. M., \& Fischer, D. G. (1988). Psychometric properties of the coach's version of the leadership scale for sports. Perceptual and Motor Skills, 67, 795-798.

Filippou, F., Rokka, S., Pitsi, A., Gargalianos, D., Bebetsos, E., \& Filippou, D. A. (2018). Interdisciplinary Greek traditional dance course: Impact on student satisfaction and anxiety. International Journal of Instruction, 11(3), 363-374.

García-Dantas, A., \& Caracuel, J. C. (2011). Factores que influyen en el abandono del alumnado de un conservatorio profesional de danza. Revista Iberoamericana de Psicología del Ejercicio y el Deporte, 6(1), 79-96.

García-Dantas, A., Caracuel-Tubío, J. C., \& Peñaloza-Gómez, R. (2013). Intervención formativa con el profesorado de danza e influencia motivacional en su alumnado. Cuadernos de Psicología del Deporte, 13(2), 9-20.

Goudini, R., Saemi, E., Ashrafpoornavaee, S., \& Abdoli, B. (2018). The effect of feedback after good and poor trials on the continuous motor tasks learning. Acta Gymnica, 48(1), 3-8. doi: 10.5507 / ag.2018.001.

Granados, D. I. (2016). Motivación, autoconcepto físico, evaluación de las competencias docentes y posibles causas de abandono en las enseñanzas básicas de danza en los conservatorios profesionales de Andalucía (Unpublished doctoral dissertation) Universidad de Granada.

Graupera, J. L., Ruiz, L. M., García, V., \& Smith, R. E. (2011). Development and validation of a Spanish version of the athletic coping skills inventory, ACSI-28. Psicothema, 23(3), 495-502.

Gustems, J., Calderón D., \& Oriola S. (2015) Music and leadership: The role of the conductor. Int. J. of Music and Perf. Arts, 3(1), 84-88. doi: 10.15640/ijmpa.v3n1a8.

Hastie, P. A. (1993). Coaching preferences of high school girl volleyball players. Perceptual and Motor Skills, 77, 1309-1310.

Hastie, P. A. (1995). Factors affecting coaching preferences of secondary school volleyball players. Perceptual and Motor Skills, 80, 347-350.

Horne, T., \& Carron, A. V. (1985). Compatibility in coach-athlete relationships. Journal of Sport Psychology, 7, 137-149. doi: 10.1123/jsp.7.2.137.

Leblon, B. (2005). Gitanos y moros en la vuelta musical al Mediterráneo hacia Andalucía, un lugar de encuentro entre Oriente y Occidente. $O$ Tchatchipen: lil ada trin tchona rodipen romani $=$ three-monthly journal of Romani research, 49, 33-39.

Ley 10/2015, de 26 de mayo, para la salvaguardia del Patrimonio Cultural Inmaterial. (BOE núm. 299, del 12 de diciembre de 2018).

Melero F. M. (2014). Estudio de las variables que participan en los estilos de liderazgo de entrenadores deportivos de baloncesto desde el modelo multidimensional. Liminales. Escritos Sobre Psicología y Sociedad, 5, 71-94. 
Miquel, S., Bigné, E., Lévy, J. P., Cuenca, A. C., \& Miquel, Mª J. (2000). Investigación de mercados. Madrid: Mc Graw-Hill.

Moreno, J. A., Cano, F., González-Cutre, D., Cervelló, E. M., \& Ruiz, L. M. (2009). Flow disposicional en salvamento deportivo: Una aproximación desde la teoría de la autodeterminación. Revista de Psicología del Deporte, 18(1), 23-35.

Moreno, J. A., Cervelló, E. M., \& González-Cutre, D. (2010). The achievement goal and self-determination theories as predictors of dispositional flow in young athletes. Anales de Psicología, 26(2), 390-399.

Pablo, E., \& Navarro J. L. (2007). Figuras pasos y mudanzas. Claves para conocer el baile flamenco. Córdoba: Almuzara.

Pantoja Antúnez, J. L. (1963). Evocación de las grandes figuras del flamenco. Jérez de la Frontera: Asta Regia.

Pedraja L. (2012). Desafíos para el profesorado en la sociedad del conocimiento. Revista Chilena de Ingeniería, 20(1), 136-144.

Pérez- Castaño, A., \& Amado, D. (2015). Importancia del estudio de la inteligencia emocional en el flamenco, Cultura, Ciencia y Deporte, 11(10), S127.

Real Decreto 85/2007, de 26 de enero, por el que se fijan los aspectos básicos del currículo de las enseñanzas profesionales de danza reguladas por la Ley Orgánica 2/2006, de 3 de mayo, de Educación. (BOE núm. 38, 13 febrero 2007)

Sáiz, S. J., \& Calvo, A. L. (2010). El buen entrenador como experto adaptativo que lidera al grupo. Revista de Psicología del Deporte, 19(1), 9-21.

Sánchez Oliva, D., Leo Marcos, F. M., Sánchez-Miguel, P. A., Amado Alonso, D., \& García-Calvo, T. (2010). Relación del clima motivacional creado por el entrenador con la motivación autodeterminada y la implicación hacia la práctica deportiva. RICYDE. Revista Int. de Ciencias del Deporte, 6(20), 177-195. doi:10.5332/ricyde2010.02001.

Salminen, S., \& Luikkonen, J. (1994). The convergent and discriminant validity of the coach's version of the leadership scale for sports. Int. J. of Sport Psyc., 25, 119-127.

Schensul, J. J., \& LeCompte, M. D. (1999). Enhanced ethnographic methods. London: Altamira.

Sharon, I. (2016). Claves para entender el coaching. Smart coach. Peru: Int. Academy.

Sherman, C. A., Fuller, R., \& Speed, H. D. (2000). Gender comparisons of preferred coaching behaviours in Australian sports. Journal of Sport Behavior, 23(4), 389-406.

Schwartz, D. L., Bransford, J. D., \& Sears, D. (2005). Efficiency and innovation in transfer. Transfer of Learning from a Modern Multidisciplinary Perspective, 1-51.

Taylor, J., \& Taylor, C. (2008). Psicología de la danza. Madrid: Gaia Ediciones.

Williams, S. J., \& Kendall, L. (2007). Perceptions of elite coaches and sports scientists of the research needs for elite coaching practice. Journal of Sports Sciences, 25(14), 1577-1586. doi:10.1080/02640410701245550. 